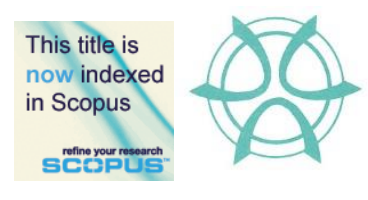

PLANNING MALAYSIA:

Journal of the Malaysian Institute of Planners

VOLUME 15 ISSUE 3 (2017), Page 13 - 26

\title{
AN IMPLEMENTATION APPROACH TO SPATIAL PLANNING IN IRAN CASE STUDY: THE SOUTH ALBORZ MACROREGION
}

\author{
Masoud Taghvaei ${ }^{1}$, Hasan Beik Mohammadi ${ }^{2}$, Nader Zali ${ }^{3}, \&$ Mitra Kasaei $^{4}$ \\ 'UNIVERSITY OF ISFAHAN, IRAN \\ ${ }^{2,4}$ SHAKHESPAJOUH RESEARCH INSTITUTE, ISFAHAN, IRAN \\ ${ }^{3}$ UNIVERSITY OF GILAN, IRAN
}

\begin{abstract}
Despite being in existence for over seven decades, spatial planning policies in Iran have not been implemented and no serious volition to adopt their general approaches was observed. This study identifies the effective factors of the spatial planning implementation approach in the macroregion around south Alborz. By adopting the Delphi technique, a cross-impact matrix and data analysis using MICMAC software, the impact of these factors on the non-implementation of spatial planning in Iran was investigated. The results show that the existence of a central planning system, the dominance of economic and sectoral planning, the lack of integrated land-planning system are among the effective factors in the spatial planning approach in Iran. Therefore, suitable solutions to eliminate the drawbacks are proposed.
\end{abstract}

Keyword: Implementation approach, spatial planning, South Alborz Macroregion (Iran), MICMAC software.

Date Received: $13^{\text {th }}$ November 2016

Date of Acceptance: $24^{\text {th }}$ August 2017 
Masoud Taghvaei, Hasan Beik Mohammadi, Nader Zali, \& Mitra Kasaei

An Implementation Approach to Spatial Planning in Iran Case Study: The South Alborz Macroregion

\section{INTRODUCTION}

Spatial planning concerns knowing the land's capabilities and understanding precedents and subsequent chains and relationships. It adopts an inter-sectoral attitude and a geographical and spatial approach, using the latter to identify its priorities with respect to other parts of the land, and it defines its impacts on the region's spatial organization and settlement patterns. The purpose of spatial planning is to add a new aspect to planning, which is the activity involved in human organization and distribution procedures throughout a national land (Regional Planning Office, 1997).

Spatial planning has always been one of the main concerns of town planners, but this type of planning has not been able to become operational in the context of medium-term plans. The obvious outcome of this has been the imbalanced distribution of resources and development opportunities in the land and intensification of spatial inequalities through concentration of resources and investment at the growth poles. Therefore, it is essential to implement national planning missions and qualities at the provincial level in order to implement national planning policies and to meet the planners' expectations, in the context of combining the land or sectoral perspectives, to ensure, through spatial planning, inter-sectoral, inter-regional and sectoral-regional coordination.

\section{RESEARCH BACKGROUND}

Spatial planning implementation approach has been considered in previous studies. The European approach to spatial planning is summarized in the European Spatial Development Perspective (ESDP), which was proposed by the European Commission for implementation by Member States of the European Union. It has been implemented by the Dutch, and a significant part of it is devoted to large ecological networks, environmental reconstruction plans and polycentric urban systems (Faludi, 2000).

Since 1996, the European Union has tried to broaden and modernize the methods of planning and spatial contribution in the European region, wherein such spatial development contributions have been evaluated through financial, official and organizational structures (Harris \& Hooper, 2002). The contribution is based on the commonly available plans to achieve political goals in the direction of the ESDP. In addition, the idea of creating a European Spatial Planning Operation Network (ESPON) has been proposed by the European Spatial Development Commission (van Gestel \& Faludi, 2005). The Netherlands could surpass other European countries by using a specific coordinator in development planning projects and hiring competent consultants (Grijzen, 2010).

Of the developing countries in Asia, India presents an example of significant progress in spatial planning. With a population of more than one billion (from 1998 onwards) and lacking underground and natural resources, India has approached spatial planning issue in a different way. Like other 
PLANNING MALAYSIA

Journal of the Malaysia Institute of Planners (2017)

developing countries, India has a great problem: limited access to spatial planning maps and images. Even if they are available, they are not up-to-date and, therefore, they cannot properly show any spatial planning variations (Gautam \& Raghavswamy, 2004).

Meanwhile, in Iran, spatial planning has been in different forms, including different types of rural exploitation. Sheikh Bahaei's petition is one of the more valuable documents of regional planning in terms of a spatial planning programme (Ramesht, 1996). The modern thinking behind spatial planning in Iran, however, was first proposed in societal studies by the University of Tehran Research Institute in a report entitled Issue of Population Growth: Tehran and Notes About Policy Development Projects in late 1966 (Department of Sociology, 1966). At the time, the term 'spatial planning' was not yet common, compared to the French term aménagement du territoire and, in the aforementioned report, the term 'country development policy' was used instead. By the beginning of the third development plan (1962-1967), regional planning activities had begun. These actions were accelerated in the fourth plan (19671972) and the country was divided into regional units by consultant engineers and ministries. Since then, at least 11 ministries and consultant engineering entities have divided the country into geographical regions. Spatial planning in Iran was prepared by Setiran Consulting Engineers in 1975. The Budget and Planning Organization invited Setiran Consulting Engineers, consisting of the French Setcupe company and its Iranian partner, to undertake the primary studies and to prepare the country's spatial planning. The results of the consultant engineers' studies have been published in a series of quarterly reports and study syntheses (Setiran Consulting Engineers, 1977).

After the Islamic Revolution, and since 1984, the second period of spatial planning began with basic studies of Islamic spatial planning and were named The Basic Practices of Islamic Spatial Planning in Iran. In 1996, spatial planning studies were recommenced. Considering that the research carried out in the years before the revolution was by Setiran Consulting Engineers, these studies could be considered as the third period of spatial planning studies in Iran. In 2004, the national criteria of spatial planning were adopted by the Council of Ministers. In 2005 , a proposed framework for a national spatial planning centre was adopted as part of organizing the economic affairs, and formation of a planning and management department.

Table 1 Classification of Spatial planning activities in Iran

\begin{tabular}{cccc}
\hline $\begin{array}{l}\text { Reasons for non- } \\
\text { execution of spatial } \\
\text { planning }\end{array}$ & Spatial planning activities & Period & Term \\
\hline $\begin{array}{c}\text { Attitudes of the } \\
\text { sovereignty of the time } \\
\text { period }\end{array}$ & $\begin{array}{c}\text { Formation of the concept of } \\
\text { Spatial planning }\end{array}$ & $\begin{array}{c}\text { The } \\
\text { beginning of } \\
1961 \text { to 1971 }\end{array}$ & First \\
\hline
\end{tabular}


Masoud Taghvaei, Hasan Beik Mohammadi, Nader Zali, \& Mitra Kasaei

An Implementation Approach to Spatial Planning in Iran Case Study: The South Alborz Macroregion

\begin{tabular}{cccc}
\hline $\begin{array}{l}\text { Reasons for non- } \\
\text { execution of spatial } \\
\text { planning }\end{array}$ & Spatial planning activities & Period & Term \\
\hline $\begin{array}{c}\text { The occurrence of the } \\
\text { revolution }\end{array}$ & $\begin{array}{c}\text { Studies of comprehensive } \\
\text { Setiran plan (first } \\
\text { experience) }\end{array}$ & 1961-1975 & Second \\
\hline $\begin{array}{c}\text { The-8year-war between } \\
\text { Iran and Iraq }\end{array}$ & $\begin{array}{c}\text { Studies of the land use } \\
\text { planning of Islamic lands of } \\
\text { Iran (second experience) }\end{array}$ & 1983-1988 & Third \\
\hline $\begin{array}{c}\text { Relative Depression Due } \\
\text { to Post-War Construction } \\
\text { Problems-Hurriedness }\end{array}$ & $\begin{array}{c}\text { Studies of Basic National } \\
\text { Development Theory (Third } \\
\text { Experience) }\end{array}$ & 1997-2005 & Fourth \\
\hline $\begin{array}{c}\text { Doubt, Redefining and } \\
\text { design of discourse with } \\
\text { the lack of consensus } \\
\text { amomg the experts }\end{array}$ & $\begin{array}{l}\text { The new era - the formation } \\
\text { of the Land use Planning } \\
\text { Council and the provincial } \\
\text { land use planning programs } \\
\text { studies (fourth experience) }\end{array}$ & 2006-So far & Fifth \\
\hline
\end{tabular}

The history of these studies in Iran (Table 1) and spatial planning structure demonstrate a need to modify the available basic rules, to increase the efficiency of the implementation process and to improve coordination between the sectors. The revision of planning law and spatial development is a priority (Podgorica Ordering Party, 2008). According to the sustainable development principles in spatial planning, the decision should be coordinated, with the involved organizations helping the implementation of spatial planning programmes at all levels by playing consultancy roles and applying the rule of law (Justice and Environment, 2013). In this study, the effective factors in the spatial planning approach was studied in the macroregion of south Alborz to provide implementation solutions for this kind of planning in Iran.

In Iran, there are few studies about this topic or on the obstacles facing the use of land. According to studies, the main reasons for not achieving spatial planning purposes have been identified as follows: a lack of coherent thinking at management level in managing the land; the lack of an adopted plan and programme for space organization; and the lack of a responsible legal entity to manage the land and to oversee the implementation of the intended spatial plans and its monitoring (Latifi, 2009). Other main obstacles to achieving the purpose of spatial planning in Iran during the last 50 years include: the regime attitude at the time (1961-1971); the Islamic Revolution (1975-1977); the Iran-Iraq War (1980-1988); reconstruction problems after the war (1988-1989); precipitance and lack of preparation (1997-2005); and the previous government's attitude (2005 to the present) (Sharifzadegan \& Razavi Dehkordi, 2010). In recent studies, the following have been identified as the most important factors in the failure of spatial planning in the Iran: lack of an exact definition of the planning position or 
PLANNING MALAYSIA

Journal of the Malaysia Institute of Planners (2017)

spatial planning perspective in legal documents directing the plans and decisions in the field of management; the governance of the oil economy; a renter economy, failing to institutionalize the spatial-regional approach; the existence of a traditional planning system that accepts the spatial planning approach in the content areas; and the existence of regional inequalities (Sarvar \& Khaliji, 2014).

\section{RESEARCH METHODOLOGY}

In the present study, the effective factors in the spatial planning implementation approach in Iran and south Alborz were identified using a combination of descriptive, documentary and causal-analytical methods, and by using questionnaires and the Delphi technique in the first phase. In the second phase, the factors which impact on each other were determined using the cross-impact matrix method in professional panels. Appropriate software (MICMAC) was then used to identify and analyse the key and effective factors.

MICMAC software has been designed to perform the complicated calculations involved in the cross-impact matrix. In order to do this, the important variables and components in the intended area are first identified and then entered into a matrix, such as the impact-analysis matrix, allowing the relationship between these variables and the related areas to be recognized by a panel of experts. The variables in the rows affect the variables in the columns. So, the total rows of variable data, the effectiveness value and the total columns of variable data show the influence value (Godet, 1991).

Six phases were carried out in the analysis of the cross-impact matrix using MICMAC software, as suggested by Asan \& Asan (2007):

- Systematic understanding and observing of the system stability or lack of stability.

- Identifying high degree direct and indirect impacts of variables.

- Identifying the main factors and drivers and using them in scenario writing.

- General understanding of the system and avoiding detailed analysis.

- Identifying the unstable system factors (factors that must be managed).

- Identifying the environment by measuring influence.

\section{Background of Study Area}

The studied region is located on the southern slope of the Alborz Mountains in an area of about $194,050 \mathrm{~km}^{2}$, which includes seven provinces, which are Zanjan, Qazvin, Alborz, Tehran, Qom, Markazi and Semnan. This region is bounded by the Alborz Mountains, Ardebil, Gilan, Mazandaran and Golestan in the north, the Zagros Mountains, East and West Azarbayjan and Province, Kordestan, Hamedan and Lorestan in the west and south-west, Dasht-e-Kavir and Isfahan, Yazd, Razavi and North Khorasan in the south, south-east and east (Research Center of Urban Development and Architecture of Iran, 2008). 
Masoud Taghvaei, Hasan Beik Mohammadi, Nader Zali, \& Mitra Kasaei

An Implementation Approach to Spatial Planning in Iran Case Study: The South Alborz Macroregion

\begin{abstract}
ANALYSIS AND FINDINGS
In order to study and analyse which factors are effective in the spatial planning implementation approach in the south Alborz macroregion, a survey was conducted to gather ideas from the participants. A series of factors were also gathered using the theoretical foundation used by the researchers. A total of 230 factors were collected. Among these proposed cases, in the first phase, 61 effective factors were finally extracted after combining overlaps and omitting unrelated and ambiguous cases. These were classified into eight groups, as shown in Table 2, where the Delphi method and scientific foundation have been used to sum up the variables.
\end{abstract}

Table 2 Characteristics of effective factors in spatial planning implementation approach and their classification for the south Alborz macroregion

\begin{tabular}{|c|c|c|}
\hline Classification & Indicators & Group \\
\hline $\begin{array}{l}\text { comprehensive understanding of the territory/ natural } \\
\text { conditions / soil and water resources / developed areas / } \\
\text { spatial organization of population and human / made } \\
\text { environment / land features use / population spatial } \\
\text { mobility / environment / issues of settlements' physical } \\
\text { expansion / the radius of industries' establishment / } \\
\text { important political centres / growth poles }\end{array}$ & $\begin{array}{l}\text { Spatial } \\
\text { organization } \\
\text { indicators }\end{array}$ & 1 \\
\hline $\begin{array}{l}\text { zoning / desert areas / political conditions / } \\
\text { neighbouring areas' security-in-charge/ organization } \\
\text { multiplicity / war and insecurity / ethnic and religious } \\
\text { issues / political pressure to implement the projects }\end{array}$ & $\begin{array}{l}\text { Political and } \\
\text { security } \\
\text { indicators }\end{array}$ & 2 \\
\hline $\begin{array}{l}\text { location data and information / spatial studies model / } \\
\text { scientific level of spatial planning preparation centres / } \\
\text { codifying goals and strategic vision / defining area / } \\
\text { common understanding of spatial planning }\end{array}$ & Content index & 3 \\
\hline $\begin{array}{l}\text { stakeholder involvement / local communities' } \\
\text { awareness / private sector partnership }\end{array}$ & $\begin{array}{l}\text { Social and } \\
\text { cultural } \\
\text { factors }\end{array}$ & 4 \\
\hline $\begin{array}{l}\text { legal status / the division of labour between devices / } \\
\text { parallel implementation / land management legal entity / } \\
\text { legal support / integrated model of spatial planning }\end{array}$ & $\begin{array}{l}\text { Legal } \\
\text { indicators }\end{array}$ & 5 \\
\hline $\begin{array}{l}\text { centralized administrative and political bureaucratic } \\
\text { structure / local and regional prejudices / a break in the } \\
\text { process of land use / stable management of planning } \\
\text { system / the system of land management and urban } \\
\text { planning / governmental look at land use / } \\
\text { integrating land use with development planning / sector } \\
\text { and territory thinking / preparation schedule / relying on } \\
\text { comparative advantages / provincial and non-regional } \\
\text { point of view / the institutionalization of land } \\
\text { preparation / officials' commitment / futuristic vision }\end{array}$ & $\begin{array}{l}\text { Management } \\
\text { and } \\
\text { administrative } \\
\text { indicators }\end{array}$ & 6 \\
\hline (C) 2017 by MIP & & \\
\hline
\end{tabular}


PLANNING MALAYSIA

Journal of the Malaysia Institute of Planners (2017)

\begin{tabular}{|c|c|c|}
\hline Classification & Indicators & Group \\
\hline $\begin{array}{l}\text { superficiality in developing programme strategies / } \\
\text { beyond regional and national considerations / } \\
\text { interaction between provinces / result-orientedness } \\
\text { rather than process orientedness / traditional views on } \\
\text { planning system in land use, view acceptance / uniform } \\
\text { description of services for all areas / sectoral view in } \\
\text { planning / }\end{array}$ & $\begin{array}{l}\text { Effective } \\
\text { factors in } \\
\text { programmatic } \\
\text { view }\end{array}$ & 7 \\
\hline $\begin{array}{l}\text { dependence on oil / spatial economy / capital and } \\
\text { financial resources (database of projects) / interaction of } \\
\text { economic process beyond peripheral areas }\end{array}$ & $\begin{array}{l}\text { Economic } \\
\text { indicators }\end{array}$ & 8 \\
\hline
\end{tabular}

The matrix dimensions are $61 \times 61$ and are set in eight different parts. The matrix filling degree is $85.72 \%$, which shows that the chosen factors have had a great and dispersive impact on each other and that, in fact, the system has been unstable. Of the 2,984 measurable variables in this matrix, 497 relationships were zero, which means that these factors, representing $14.2 \%$ of the matrix total volume, have had no impact on each other. On the other hand, based on the statistical indicators and with a 2-time data rotation, this matrix has $100 \%$ optimization, which implies a high validity of the questionnaire and its answers

In Figure 1, the distribution of variables shows the stability or lack of stability of the system. This means that some variables have high impression and some have high effectiveness. In total, three groups of variables can be observed in a stable system (Arcade et al. 2003):

- Very effective variables in the system (key factors).

- Independent variables.

- System output variables (result variables).

Based on the distribution of effective factors in the spatial planning implementation approach, it can be observed that the system is strongly unstable. Most variables are around the diameter axis of the plane. Except for a few factors, which show high effectiveness in the system, the rest of the variables have the same status in relation to each other, which are just different in intensity and weakness.

Two-dimensional variables have two common characteristics: high impression and high effectiveness. Every action on these variables will affect the others and will also cause variations. These variables can be divided into two groups: risk variables and target variables (Figure 2). Of the 61 variables 14 are in this group, which are mainly the variables related to planning and management issues and include some cases of economy and space organization. 
Masoud Taghvaei, Hasan Beik Mohammadi, Nader Zali, \& Mitra Kasaei

An Implementation Approach to Spatial Planning in Iran Case Study: The South Alborz Macroregion

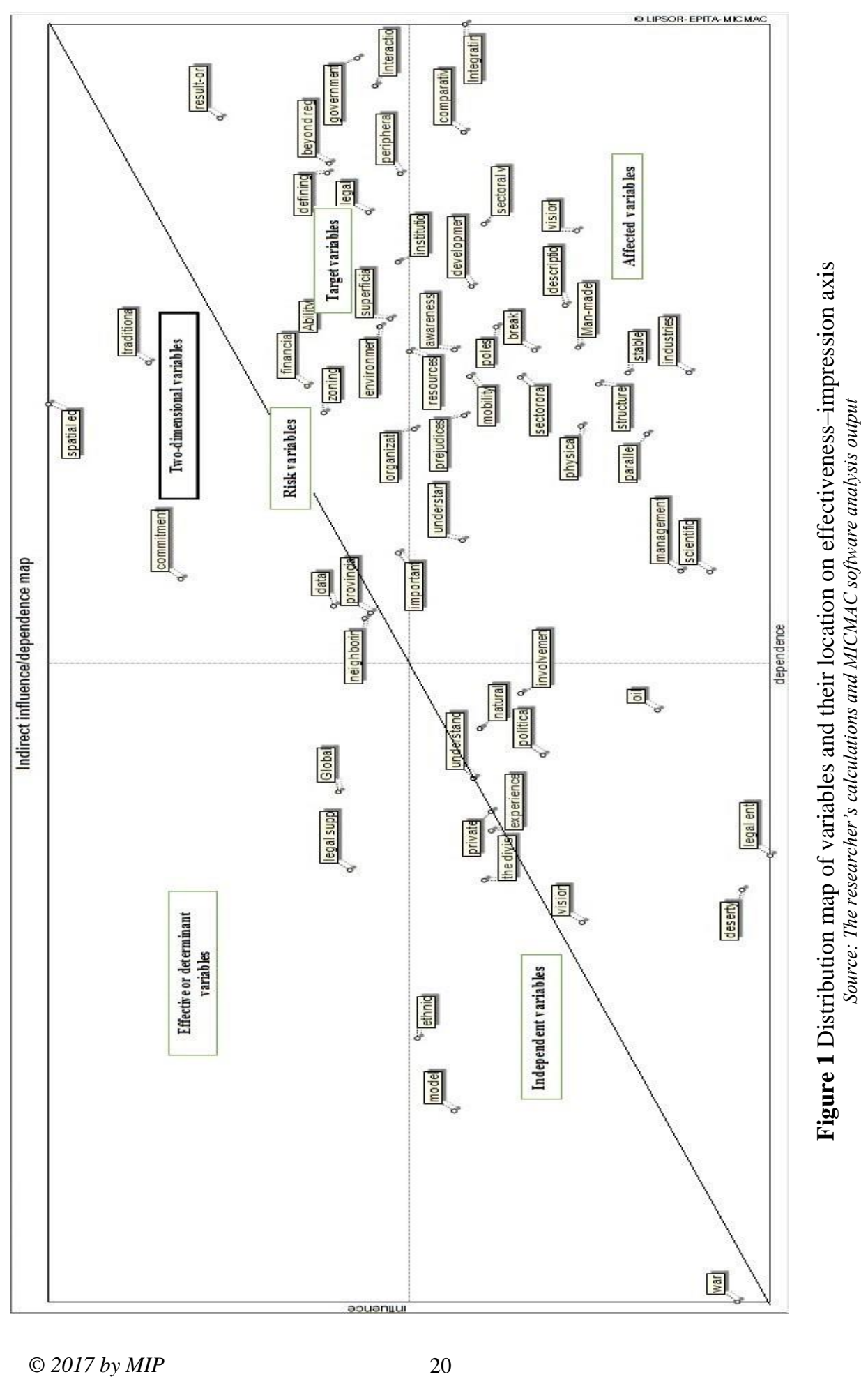


Risk variables are located near the diameter of the south-east area .These variables include the following cases: oil dependency, regional thinking, zoning, regional and national considerations, and political and security conditions in neighbouring areas. Risk variables can be mainly considered as the variables related to planning and security (Figure 2).

Target variables are located under the north-east diameter of the plane. In fact, these variables are the evolutionary results of the system and show the possible targets of a system. The variables in this group include the following: environmental, perspective, futurism, private partnership, land capabilities usage, economic performance in engagement with peripheral areas, management stability in planning systems, reliance on relative advantages, and compliance with authority (Figure 2).

Affected variables (also known as result variables) are located in the south-east area of Figure 2. These variables are strongly affected by the system and have a low degree of impression in the system. It can be said that most of these variables are related to social and spatial organization issues.

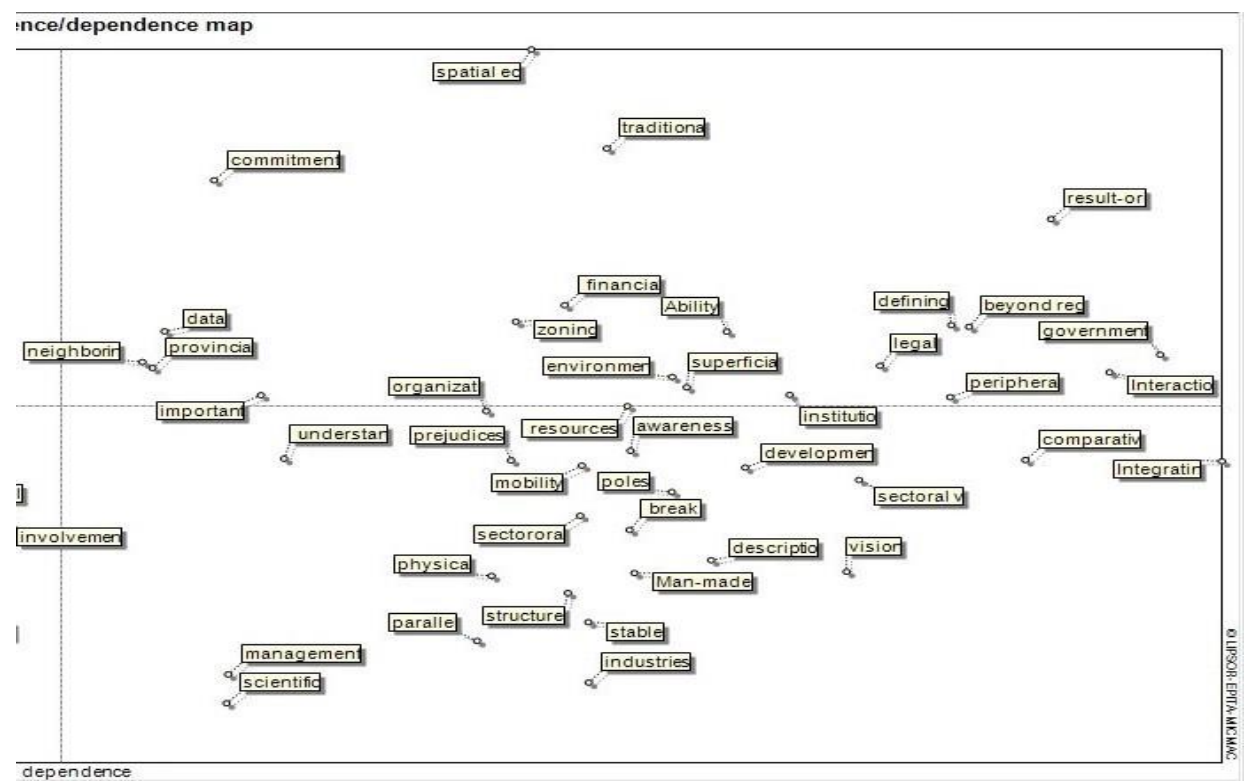

Figure 2 Distribution map of two-dimensional variables (target, risk and affected variables)

Source: MICMAC software analysis output, adapted from the right part of the Fig. 1

Factors with a high degree of effectiveness have a low presence in the north-west area of Figure 1. These include global variables, the legal entity of the land and integrated management. These are the most important effective factors in the spatial planning implementation approach as they play a much greater role. 
Masoud Taghvaei, Hasan Beik Mohammadi, Nader Zali, \& Mitra Kasaei

An Implementation Approach to Spatial Planning in Iran Case Study: The South Alborz Macroregion

Independent variables have low effectiveness and impression. They are located in the south-west of Figure 1. It seems that some of these variables have the system output nature.

The graph of direct relationships between the variables (in MICMAC software analysis output) shows that there are strong relationships between factors such as the political centre of the region, the interaction of economic performance beyond the peripheral regions, the north-south and east-west corridors, investment and financial resources of plans.

According to the results, the experts and Figures, some main factors can be recognized as the key effective factors in the spatial planning implementation approach. After studying their direct and indirect impacts on other variables and investigating single-factor graphs, the most important effective factors with a negative or positive impact on the spatial planning implementation in the south Alborz macroregion are: an integrated management system, spatial economy, attention to inter-provincial interactions, oil dependency and human resources. In Figure 3, ranking of factors with the most direct and indirect effects is displayed.

\begin{tabular}{|c|c|c|}
\hline Rank & Variable & Variable \\
\hline 1 & 57 - spatial ec & 57 - spatial ec \\
\hline 2 & 53 - traditiona & 53 - traditiona \\
\hline 3 & 47-commitment & 47-commitment \\
\hline 4 & 52 - result - on & 52 - resutt-on \\
\hline 5 & 58 - financial & 58 - financial \\
\hline 6 & 14-zoning & 14 -zoning \\
\hline 7 & 21 - data & 25 -defining \\
\hline 8 & 25 -defining & 50 - beyond reg \\
\hline 9 & 50 - beyond reg & 21-data \\
\hline 10 & 34 - legal supp & 7-Ability \\
\hline 11. & 7. Abilty & 16 -Global \\
\hline 12 & 16. Global & 34 - legal supp \\
\hline 13 & 41 - govemment & 41 - govemment \\
\hline 14 & 30 -legal & 17 - neighborin \\
\hline 15 & 45 -provincial & 30 -legal \\
\hline 16 & 17 - neighborn & 45-provincial \\
\hline 17 & 51 - Interactio & 51 - Interactio \\
\hline 18 & 9 -environmen & 9 -ernvironmen \\
\hline 19 & 49 - superficia & 49 - supperficia \\
\hline 20 & 12 - important & 46 - institutio \\
\hline 21 & 46 - institutio & 12 -important \\
\hline 22 & 59 - peripheral & 59 -peripheral \\
\hline 23 & 3- resources & 3- resources \\
\hline 24 & 5-organizati & 5 - organizati \\
\hline 25 & 19- ethric & 19. ethric \\
\hline 26 & 28 -awareness & 22 -model \\
\hline 27 & 37 -prejudices & 28 - awareness \\
\hline 28 & 22 -model & 26 - understan \\
\hline 29 & 26. understan & 44-comparativ \\
\hline 30 & 42 - Integratin & 37 - prejudices \\
\hline 31 & 44-comparativ & 42 - Integratin \\
\hline 32 & 4-developmen & 8 -mobility \\
\hline 33 & 31 - the divisi & 4- developmen \\
\hline 34 & 35 - experience & 1 - understand \\
\hline 35 & 8 -moblity & 2 - natural \\
\hline 36 & 29 -peivate & 55 - sectoral v \\
\hline 37 & 55 - sectoral v & 31 -the divisi \\
\hline
\end{tabular}

Figure 3 Ranking of variables' direct and indirect effects Source: MICMAC software analysis output 
PLANNING MALAYSIA

Journal of the Malaysia Institute of Planners (2017)

\section{DISCUSSION}

Based on the ranking in Figure 3 and prioritizing the main effective factors from the output of the MICMAC software as well as the expert reviews, the results of show that lack of an integrated spatial planning system, lack of coordination between the two methods of regional planning and land planning, a weakness in the implementation power of spatial planning policies and dependency on basic resources such as oil are the drawbacks of a spatial planning implementation approach in the south Alborz macroregion. The lack of a clear and responsible authority for land management to direct spatial planning implementation is another obstacle in Iran. Although the formation of the National Spatial Planning Center based on the Council of Ministers' directive entitled 'National Conditions of Spatial Planning' is one of the solutions to change this situation, the lack of complementary implementation and regulatory institutions have caused the intended targets to be unfulfilled.

\section{RECOMMENDATIONS}

The study shows that lack of an integrated spatial planning system hampers spatial planning implementation approach in the south Alborz macroregion. Thus, this implies that trans-regional actions such as creating interactions and parallel inter-regional relationships ${ }^{1}$ are required to make connections between different planning levels, both above and below, which should entail a mutual relationship. Reinforcing the connection between regions and creating spatial integration would lead to suitable national spatial implementation policies and solutions. Sectoral planning should also include regional and spatial effects, in order to maximize profits and to minimize loss, and planning and directing future developments using spatial structural analysis and sectoral planning.

\section{Long-term recommendations}

Based on the findings of this study, some long term recommendation are suggested, as follows:

1. To guide the implementation of spatial planning, a legal framework which makes the creation of tools and spatial planning policies possible in different spatial scales through consultancy and democratic methods should be developed.

2. To promote integrated land management, incentives and official permits should be used to assure the effectiveness and cooperation between all

\footnotetext{
1 - Parallel connection refers to the connection among neighbouring provinces in creating inter-regional integration and, consequently, a connection among the provinces with a macroregional landscape and regional connections with the national landscape.
} 
Masoud Taghvaei, Hasan Beik Mohammadi, Nader Zali, \& Mitra Kasaei

An Implementation Approach to Spatial Planning in Iran Case Study: The South Alborz Macroregion

sectors and administrative boundaries, and between different levels of government.

3. Controlling spatial planning in regional and local levels to assure adherence to the rules, following the principles and methods of compliance, and promoting the actions and policies of jurisdiction. 'SPDSS network must be developed at [the] international level and local level to improve the development capacity' (Abdullah et al., 2005).

4. Controlling the spatial trend and the spatial planning impact using indicators and targets.

\section{CONCLUSION}

The need for a proper understanding of the spatial planning concept has led to the continuation of regional, component-oriented and non-strategic plans. Spatial planning in Iran has, theoretically and practically, been reduced to small spatial scales and has actually lost its macro, national and regional view.

Spatial planning needs implementation tools at the national level, and the ruling system should provide all the necessary requirements and use them in different areas, such as in military, economic, cultural and political arenas.

Land use attitudes and perspectives should be institutionalized within the territory. Preparing a document does not guarantee its enforcement. First, there should be collaborative participation during document preparation. Second, when prepared, it should act as a tool. This means that document planning should be the basis for better thinking about short- and long-term decisions. 
PLANNING MALAYSIA

Journal of the Malaysia Institute of Planners (2017)

\section{ACKNOWLEDGEMENTS}

The authors would like to thank the planners and faculties who helped with the analyses and for their responses to this study's questionnaire.

\section{REFERENCES}

Abdullah, M. F., Abdullah, A., Ibrahim, M., \& Abdul Samad, D. (2006). A study on the demand of spatial planning and decision support system in Malaysia. Planning Malaysia, 3(1), 47-60. http://dx.doi.org/10.21837/pmjournal.v3.i1.46.

Arcade, J., Godet, M., Meunier, F., \& Roubelat, F. (2003). Structural analysis with the MICMAC method and actors' strategy with MACTOR method. In J. C. Glenn \& T. J. Gordon (Eds.), AC/UNU Millennium Project: Futures Research Methodology-V2.0. Washington DC: AC/UNU.

Asan, S. S., \& Asan, U. (2007). Qualitative cross-impact analysis with time consideration. Technological Forecasting and Social Change, 74(5), 62744. doi: 10.1016/j.techfore.2006.05.011.

Regional Planning Office (1997). Spatial Planning: The Concepts, Needs and Experiences, Tehran: Budget and Plan Organization.

Department of Sociology (Institute for Social Studies and Research) (1996). Issue of population growth: Tehran and notes about Tehran, Iran.

Faludi, A. (2000). The performance of spatial planning. Planning Practice and Research, 15(4), 299-318. http://dx.doi.org/10.1080/713691907

Gautam, N. Ch., \& Raghavswamy. V. (2004). Land use/land cover and management in India. Hyderabad: BS Publications.

van Gestel, T., \& Faludi, A.(2005). Towards a European cohesion assessment network. Town Planning Review, 76(1), 81-92.

Godet, M. (1991). From anticipation to action. Paris: UNESCO Publishing.

Grijzen, J. (2010).Outsourcing planning: What do consultants do in regional spatial planning in the Netherlands. Amsterdam: Amsterdam University.

Harris, N., \& Hooper, A. (2002). The preparation of the Wales Spatial Plan. Town and Country Planning Association, 71, 133-7.

Justice and Environment (2013). Public participation in spatial planning procedures: comparative study of six EU member states. Retrieved September 1, 2016 from www.justiceandenvironment.org.

Latifi, Gh. H. (2009). A brief look at some of the theories in place in regional planning. Tehran: Book of the Month. [IN PERSIAN].

Podgorica Ordering Party (2008). Spatial Plan of Montenegro until 2020 (Montenegroinženjering). Podgorica: Ministry of Economic Development.

Ramesht, M. H. (1996). The use of geomorphology in national, regional and economic planning. Isfahan: University of Isfahan. [IN PERSIAN]. 
Masoud Taghvaei, Hasan Beik Mohammadi, Nader Zali, \& Mitra Kasaei

An Implementation Approach to Spatial Planning in Iran Case Study: The South Alborz Macroregion

Research Center of Urban Development and Architecture of Iran (2008). Southern Alborz physical layout: summary of studies of the first to fourth. Tehran: Research Center of Urban Development and Architecture of Iran.

Sarvar, R., \& Khaliji, M.A. (2014). Pathology land use planning in Iran. In the First National Conference on New Approaches to Land Use Planning in Iran. Semnan University. [IN PERSIAN].

Setiran Consulting Engineers (1947). Studies of land use basic plan. Tehran: Budget and Plan Organization.

Sharifzadegan, M. H., \& Razavi Dehkordi, S. A. (2010). Evaluating the land use planning process in Iran and ways to improve it. Environmental Sciences Quarterly, 4, 87-100. [IN PERSIAN]. 